\title{
SOIL PHOSPHORUS DYNAMICS AND AVAILABILITY AND IRRIGATED COFFEE YIELD ${ }^{(1)}$
}

\author{
Thiago Henrique Pereira Reis ${ }^{(2)}$, Paulo Tácito Gontijo Guimarães ${ }^{(3)}$, Antônio \\ Eduardo Furtini Neto ${ }^{(4)}$, Antônio Fernando Guerra ${ }^{(5)} \&$ Nilton Curi ${ }^{(6)}$
}

\begin{abstract}
SUMMARY
Research data have demonstrated that the P demand of coffee (Coffea arabica L.) is similar to that of short-cycle crops. In this context, the objective of this study was to evaluate the influence of annual $P$ fertilization on the soil $P$ status by the quantification of labile, moderately labile, low-labile, and total $\mathbf{P}$ fractions, associating them to coffee yield. The experiment was installed in a typical dystrophic Red Latosol (Oxisol) cultivated with irrigated coffee annually fertilized with triple superphosphate at rates of $0,50,100,200$, and $400 \mathrm{~kg} \mathrm{ha}^{-1} \mathrm{P}_{2} \mathrm{O}_{5}$. Phosphorus fractions were determined in two soil layers: 0-10 and 10-20 cm. The $P$ leaf contents and coffee yield in 2008 were also evaluated. The irrigated coffee responded to phosphate fertilization in the production phase with gains of up to $138 \%$ in coffee yield by the application of $400 \mathrm{~kg} \mathrm{ha}^{-1} \mathrm{P}_{2} \mathrm{O}_{5}$. Coffee leaf $\mathrm{P}$ contents increased with $P$ applications and stabilized around $1.98 \mathrm{~g} \mathrm{~kg}^{-1}$, at rates of $270 \mathrm{~kg} \mathrm{ha}^{-1} \mathrm{P}_{2} \mathrm{O}_{5}$ and higher. Soil $\mathrm{P}$ application caused, in general, an increase in bioavailable $\mathbf{P}$ fractions, which constitute the main soil $\mathbf{P}$ reservoir.
\end{abstract}

Index terms: Coffee arabica L., phosphate fertilization, phosphorus fractionation.

\footnotetext{
(1) Received for publication in May 2010 and approved in January 2011.

(2) Soil Science Doctorate Student, Soil Science Departament, Universidade Federal de Lavras - UFLA. Mail Box 3037, CEP 37200000 Lavras (MG), Brazil. CNPq Scholarship. E-mail: thiagohpreis@yahoo.com.br

(3) Researcher, Empresa de Pesquisa Agropecuária de Minas Gerais - EPAMIG, South of Minas Regional Unity. Campus da UFLA, Lavras (MG), Brazil. FAPEMIG Scholarship. E-mail: paulotgg@epamig.ufla.br

${ }^{(4)}$ Associated Professor, Soil Science Departament, UFLA. CNPq Scholarship. E-mail: afurtini@dcs.ufla.br

${ }^{(5)}$ Researcher, Empresa Brasileira de Pesquisa Agropecuária - Embrapa Cerrados. Mail Box 08223, Road BR 020 Km 18, CEP 73310-970 Planaltina (DF), Brazil. E-mail: guerra@cpac.embrapa.br

(6) Titular Professor, Soil Science Departament, UFLA. CNPq Scholarship. E-mail: niltcuri@dcs.ufla.br
} 


\title{
RESUMO: DINÂMICA E DISPONIBILIDADE DE FÓSFORO NO SOLO E PRODUTIVIDADE DO CAFEEIRO IRRIGADO
}

\begin{abstract}
Resultados de pesquisa têm demonstrado que o cafeeiro demanda uma quantidade anual de fósforo semelhante à das culturas de ciclo curto. Nesse contexto, o objetivo deste trabalho foi avaliar o status do P no solo, em função da aplicação anual de doses de P, por meio da quantificação de frações de P lábeis, moderadamente lábeis, pouco lábeis e P total, associandoas às produtividades do cafeeiro. O experimento foi instalado num Latossolo Vermelho distrófico típico $(L V d)$ cultivado com cafeeiros irrigados em produção, submetidos a adubações fosfatadas anuais de 0,50,100, 200 e $400 \mathrm{~kg} \mathrm{ha}^{-1}$ de $\mathrm{P}_{2} \mathrm{O}_{5}$, como superfosfato triplo. Foram determinadas frações de fósforo no solo nas profundidades de 0-10 e 10-20 cm. Também foram avaliados teores foliares de fósforo e a produção dos cafeeiros em 2008. O cafeeiro irrigado respondeu à adubação fosfatada em fase de produção, com incrementos de até $138 \%$ na produtividade com a aplicação de $400 \mathrm{~kg} \mathrm{ha}{ }^{-1}$ de $\mathrm{P}_{2} \mathrm{O}_{5}$, na safra avaliada. Os teores foliares de $P$ no cafeeiro aumentaram com o aumento das doses de P e se estabilizaram em torno de $1,98 \mathrm{~g} \mathrm{~kg}^{-1}$ a partir da dose de $270 \mathrm{~kg} \mathrm{ha}^{-1}$ de $\mathrm{P}_{2} \mathrm{O}_{5}$. A aplicação de fósforo ao solo promoveu, em geral, incrementos nas frações de $P$ biodisponíveis, sendo estas o principal reservatório de $P$ do solo.
\end{abstract}

Termos de indexação: Coffea arabica L., adubação fosfatada, fracionamento de fósforo.

\section{INTRODUCTION}

The expansion of the agricultural frontier in Brazil has advanced, mainly, towards Cerrado areas, where soils have good physical properties and topography is favorable for mechanization. However, the establishment and development of most crops is limited in the majority of Cerrado soils, due to effects of high acidity, high exchangeable Al-saturation values and general nutrient deficiency, mainly of $\mathrm{P}$ (Sousa et al., 2007). The contents of available $\mathrm{P}$ in these soils are generally well below the critical level, limiting normal crop growth and development and, therefore, requiring large amounts of $\mathrm{P}$ to provide crops with appropriate levels of this nutrient.

As a result of the equilibrium reactions in acidic soils, $\mathrm{P}$ occurs predominantly as orthophosphate ion $\left(\mathrm{H}_{2} \mathrm{PO}_{4}{ }^{-}\right)$in soil solution. In the soil solid phase it combines with $\mathrm{Fe}, \mathrm{Al}$ and $\mathrm{Ca}$, mainly (Raij et al., 2001). Reactions of $\mathrm{P}$ with soil mineralogical components of the clay fraction also occur, mainly in Brazilian soils which are relatively rich in $\mathrm{Fe}$ and $\mathrm{Al}$ oxides and kaolinite (Raij, 2004).

For decision making on the need and definition of phosphate fertilizer rates and application forms, it is important to understand the basic phenomena of soil $\mathrm{P}$ dynamics, associated to the environmental factors that control the activity of microorganisms, and soil physical, chemical and mineralogical properties. In highly weathered soils, the inorganic $\mathrm{P}$ forms bonded to mineral fraction and the physically and chemically stabilized organic forms predominate, which can be characterized as labile and non-labile, according to the stability degree of these compounds (Rheinheimer et al., 2008).
Plants differ in growth capacity according to the soil P contents (Bhadoria et al., 2002). Historically, coffee has been considered little P-responsive in the production phase, because this macronutrients is one of the least required and exported by the crop. However, some recent research results have shown that coffee responds to $\mathrm{P}$ application in systems with high productivity, probably due to the higher energy demand for metabolic processes (Guerra et al., 2007).

In this context, the concern to find methods for a better understanding of soil $\mathrm{P}$ dynamics and availability is great. The fractionation of $\mathrm{P}$ is a tool of characterization of the nutrient in the soil, based on the availability to plants in the short and long term, which determines the $\mathrm{P}$ compartments with different chemical stability degrees (Silva et al., 2003). Furthermore, the distinction of $\mathrm{P}$ fractions plays an important role in the prediction of the soil $\mathrm{P}$ behavior, and in associations of $\mathrm{P}$ with routine extractors it makes a better understanding of the $\mathrm{P}$ dynamics and plant availability possible.

The objective of this study was to evaluate the dynamics of $\mathrm{P}$ fractions in a very clayey Latosol under irrigated coffee and coffee leaf $\mathrm{P}$ contents and yield in response to annual $\mathrm{P}$ applications.

\section{MATERIAL AND METHODS}

The experiment was initiated in January 2001, in a very clayey typical dystrophic Red Latosol (LVd) (Oxisol), (lat $15^{\circ} 35^{\prime} 42^{\prime}$ S, long $47^{\circ} 43^{\prime} 51^{\prime}$ W, $1009 \mathrm{~m}$ asl) in Planaltina, Distrito Federal.

The cultivar Rubi MG-1192 was used, in a spacing of $2.8 \times 0.5 \mathrm{~m}$, fertilized at planting according to 
recommendations of the Comissão de Fertilidade do Solo do Estado de Minas Gerais-CFSEMG (1999). Starting at the first flowering, in 2002 , the annual $\mathrm{P}$ rates $\left(0 ; 50 ; 100 ; 200\right.$ and $\left.400 \mathrm{~kg} \mathrm{ha}^{-1} \mathrm{P}_{2} \mathrm{O}_{5}\right)$ were in the area under the tree canopy, using triple superphosphate. Two thirds were applied in September, before resuming irrigations (after the water stress period), and $1 / 3$ between the end of December and beginning of January. Annual rates of $500 \mathrm{~kg} \mathrm{ha}^{-1} \mathrm{~N}$ in the form of urea, $500 \mathrm{~kg} \mathrm{ha}^{-1} \mathrm{~K}_{2} \mathrm{O}$ in the form of $\mathrm{KCl}$ and $100 \mathrm{~kg} \mathrm{ha}^{-1} \mathrm{FTE} \mathrm{BR} 10$ $(\mathrm{Zn}=7 \% ; \mathrm{B}=2.5 \% ; \mathrm{Cu}=1 \% ; \mathrm{Fe}=4 \% ; \mathrm{Mn}=4 \%$; $\mathrm{Mo}=0.1 \% ; \mathrm{Co}=0.1 \%$ ) were applied for micronutrient supply. $\mathrm{N}$ and $\mathrm{K}$ were split in four applications from September to February. Phytosanitary treatments, when necessary, were the same for all plots. The experimental was arranged in a randomized block design, with three replications, where the blocks consisted of three rows, of which the rows on either side were borders and only the central row was evaluated. The plots consisted of 10 plants, of which the central eight were evaluated. The area was irrigated (center pivot) under moderate hydric stress to synchronize reproductive bud development and ensure uniformity of flowering.

In 2005 , the plants of the experiment were pruned by cutting the plagiotropic branches to a length of $0.4 \mathrm{~m}$ and the orthotropic branch at $1.5 \mathrm{~m}$ height. In the experimental plots, in 2007, soil samples were collected from two layers (0-10 and 10-20 cm), prior to fertilization for the growing season 2007/2008. From each layer, composite samples were collected from different points, clearly separating the layers. In 2008, at harvest, the plots were sampled again as in the year before.

Composite soil samples were collected for chemical characterization ( $\mathrm{pH}$ in water, $\mathrm{K}, \mathrm{Ca}^{2+}, \mathrm{Mg}^{2+}, \mathrm{Al}$, $\mathrm{H}+\mathrm{Al}, \mathrm{P}$, remnant $\mathrm{P}$, organic C) (Embrapa, 2009). The total free Fe oxide contents were determined in four successive extractions with citrate-bicarbonatedithionite $\left(\mathrm{Fe}_{\mathrm{d}}\right)$ (Mehra \& Jackson, 1960), the less crystalline Fe oxide contents by a single extraction with ammonium oxalate ( $\mathrm{Fe}_{\mathrm{o}}$ ) (Schwertmann, 1964) and the $\mathrm{P}$ contents by sulfuric acid attack (Embrapa, 2009). The kaolinite and gibbsite contents in the clay fraction were estimated by allocation (Resende et al., 1987) and those of hematite and goethite based on the soil color and $\mathrm{Fe}_{\mathrm{d}}$ contents (Torrent et al., 1983). The maximum $\mathrm{P}$ adsorption capacity (MPAC) was determined according to Syers et al. (1973). In the physical analysis, granulometry was determined by the pipette method (Embrapa, 2009) (Table 1).

Phosphorus availability was evaluated by Mehlich-1 ( $\mathrm{HCl} 0.05 \mathrm{~mol} \mathrm{~L}^{-1}+\mathrm{H}_{2} \mathrm{SO}_{4} 0.0125 \mathrm{~mol} \mathrm{~L}^{-1}$ ) (Embrapa, 2009) and ionic exchange resin extractors (Raij \& Quaggio, 2001). Phosphorus fractions were also determined according to the modified method of Hedley et al. (1982) and total $\mathrm{P}$ according to Bowman (1989).
Table 1. Chemical and physical attributes of the dystrophic Red Latosol (Oxisol) at 0-10 and 10$20 \mathrm{~cm}$, prior to the study

\begin{tabular}{|c|c|c|}
\hline \multirow{2}{*}{ Soil attributes } & \multicolumn{2}{|c|}{ LVd - Depths (cm) } \\
\hline & 0-10 & $10-20$ \\
\hline pH (water) & 4.8 & 4.8 \\
\hline $\mathrm{K}\left(\mathrm{mg} \mathrm{dm} \mathrm{m}^{-3}\right)$ & 140 & 126 \\
\hline $\mathrm{Ca}^{2+}\left(\mathrm{cmol}_{\mathrm{c}} \mathrm{dm}^{-3}\right)$ & 1.0 & 1.2 \\
\hline $\mathrm{Mg}^{2+}\left(\mathrm{cmol}_{\mathrm{c}} \mathrm{dm}^{-3}\right)$ & 0.3 & 0.3 \\
\hline $\mathrm{Al}^{3+}\left(\mathrm{cmol}_{\mathrm{c}} \mathrm{dm}^{-3}\right)$ & 1.0 & 0.9 \\
\hline $\mathrm{H}+\mathrm{Al}\left(\mathrm{cmol}_{\mathrm{c}} \mathrm{dm}^{-3}\right)$ & 10.4 & 8.6 \\
\hline $\mathrm{m}(\%)$ & 40 & 41 \\
\hline Organic Matter $\left(\mathrm{g} \mathrm{kg}^{-1}\right)$ & 39 & 33 \\
\hline P-Mehlich-1 (mg dm $\left.{ }^{-3}\right)$ & 3.3 & 1.4 \\
\hline P-Resin $\left(\mathrm{mg} \mathrm{dm}^{-3}\right)$ & 3.9 & 1.1 \\
\hline Remnant P (mg kg $\left.{ }^{-1}\right)$ & 4.5 & 4.3 \\
\hline Sand $\left(\mathrm{g} \mathrm{kg}^{-1}\right)$ & 18 & 18 \\
\hline Silt $\left(\mathrm{g} \mathrm{kg}^{-1}\right)$ & 14 & 14 \\
\hline Clay $\left(\mathrm{g} \mathrm{kg}^{-1}\right)$ & 68 & 68 \\
\hline $\operatorname{MPAC}\left(\mathrm{mg} \mathrm{kg}^{-1}\right)$ & 1185 & 1187 \\
\hline Total $\mathrm{P}_{2} \mathrm{O}_{5}\left(\mathrm{~g} \mathrm{~kg}^{-1}\right)$ & 5 & 4 \\
\hline Free Iron $\left(\mathrm{Fe}_{\mathrm{d}}\right)\left(\mathrm{g} \mathrm{kg}^{-1}\right)$ & 97.5 & 98.0 \\
\hline Less crystalline iron $\left(\mathrm{Fe}_{\mathrm{o}}\right)\left(\mathrm{g} \mathrm{kg}^{-1}\right)$ & 1.43 & 1.40 \\
\hline $\mathrm{Fe}_{\mathrm{o}} / \mathrm{Fe}_{\mathrm{d}}$ & 0.015 & 0.014 \\
\hline Kaolinite (Ct) $\left(\mathrm{g} \mathrm{kg}^{-1}\right)$ & 370 & 375 \\
\hline Gibbsite $(\mathrm{Gb})\left(\mathrm{g} \mathrm{kg}^{-1}\right)$ & 270 & 275 \\
\hline $\mathrm{Gb} /(\mathrm{Gb}+\mathrm{Ct})$ & 0.42 & 0.42 \\
\hline Hematite $(\mathrm{Hm})\left(\mathrm{g} \mathrm{kg}^{-1}\right)$ & 13 & 15 \\
\hline Goethite (Gt) $\left(\mathrm{g} \mathrm{kg}^{-1}\right)$ & 84 & 86 \\
\hline $\mathrm{Gt} /(\mathrm{Gt}+\mathrm{Hm})$ & 0.87 & 0.85 \\
\hline
\end{tabular}

m (\%): saturation by $\mathrm{Al}$ in soil effective CEC; MPAC: Maximum Phosphorus Adsorption Capacity.

In the fractionation proposed by Hedley et al. (1982), labile inorganic $\mathrm{P}\left(\mathrm{Pi}-\mathrm{NaHCO}_{3}\right)$ and organic $\mathrm{P}(\mathrm{Po}-$ $\mathrm{NaHCO}_{3}$ ), adsorbed on the colloid surfaces were extracted with $\mathrm{NaHCO}_{3} 0.5 \mathrm{~mol} \mathrm{~L}^{-1}$. Moderately labile inorganic $\mathrm{P}(\mathrm{Pi}-\mathrm{NaOH})$, associated to $\mathrm{Fe}$ and $\mathrm{Al}$ oxides and organic $\mathrm{P}$ (Po-NaOH), associated to humic compounds, were extracted with $\mathrm{NaOH} 0.1 \mathrm{~mol} \mathrm{~L}^{-1}$; and little labile inorganic $\mathrm{P}(\mathrm{Pi}-\mathrm{NaOH})$, associated to $\mathrm{Fe}$ and $\mathrm{Al}$ oxides and organic $\mathrm{P}(\mathrm{Po}-\mathrm{NaOH})$, associated to humic compounds, were extracted with $\mathrm{NaOH}$ $0.5 \mathrm{~mol} \mathrm{~L}^{-1}$. Total soil $\mathrm{P}$ was determined by digestion at $120{ }^{\circ} \mathrm{C}$, in concentrated acid medium and sequentially in alkaline medium (Bowman, 1989). Phosphorus was determined by molecular absorption spectroscopy in all extracts, according to Murphy \& Riley (1962).

For the plant tissue material, leaves were collected from the middle third of the trees, from the third pair of plagiotropic branch leaves, before the grain filling stage (December, 2007). After washing with distilled water the leaves were dried to constant weight at $60{ }^{\circ} \mathrm{C}$, in a forced-air oven. Later, they were ground and, through nitric-perchloric extract, the $\mathrm{P}$ content was determined by molecular absorption spectroscopy (Embrapa, 2009). 
The obtained data were submitted to variance analysis and t tests, using statistical software Sisvar (Ferreira, 2000) adjusting regression equations for different $\mathrm{P}$ forms, yield and leaf $\mathrm{P}$ content as variables related to the $\mathrm{P}_{2} \mathrm{O}_{5}$ rates.

\section{RESULTS AND DISCUSSION}

The coffee yield in 2008 harvest increased linearly in relation to $\mathrm{P}_{2} \mathrm{O}_{5}$ rates (Figure 1a). The increase induced by the highest $\mathrm{P}$ rate reached $138 \%$, a production of 125.7 bags ha-1 $^{-1}$, compared to the control without $\mathrm{P}\left(50.7\right.$ bags ha $\left.^{-1}\right)$.

These results are remarkable when compared to other studies in the literature reporting coffee yield increases in the order of $12-16 \%$, when rates of 0 $180 \mathrm{~kg} \mathrm{ha}^{-1} \mathrm{P}_{2} \mathrm{O}_{5}$ were evaluated (Gallo et al., 1999; Prezotti \& Rocha, 2004). On the other hand, Guerra et al. (2007) related linear coffee responses to annual $\mathrm{P}$ rates in the order of $73.4 \%$, i.e., 30.5 bags ha $^{-1}$, compared to the control, when annual rates of $400 \mathrm{~kg} \mathrm{ha}^{-1} \mathrm{P}_{2} \mathrm{O}_{5}$ were applied for three consecutive seasons.

The highest $\mathrm{P}_{2} \mathrm{O}_{5}$ rate led to an average coffee yield gain of $86 \%$ ( 69.9 bags ha $^{-1}$ year ${ }^{-1}$ ) over the control (37.6 bags ha ${ }^{-1}$ year $\left.^{-1}\right)$ in the study years (Table 2 ). No response of coffee was observed to the lowest $\mathrm{P}$ rates (50 and $100 \mathrm{~kg} \mathrm{ha}^{-1} \mathrm{P}_{2} \mathrm{O}_{5}$ ), indicating that a considerable part of these $P$ rates was fixed by the soil and did not appropriately meet the coffee plants' nutritional needs. However, these rates are close to those officially recommended for an expected coffee yield of 70 bags ha $^{-1}$ (Raij et al., 1997; CFSEMG, 1999). Furthermore, an average coffee yield of around 40 bags ha ${ }^{-1}$ year $^{-1}$ corresponds to the production of a well-run coffee farm, at this soil fertility level.

The coffee yield in the treatment without $\mathrm{P}$ application, although lower than in the other treatments, was also good in the years of the experiment due to an application of phosphate fertilization in the total area followed by incorporation and new addition of phosphate in the coffee plant planting furrow (CFSEMG, 1999). It should also be emphasized that the relationship between water availability (irrigation) and nutrient absorption is quite close, mainly in the case of $\mathrm{P}$, which is transferred to the roots by diffusion.

In a general way, the gain in coffee yield was highest by an annual rate of $200 \mathrm{~kg} \mathrm{ha}^{-1} \mathrm{P}_{2} \mathrm{O}_{5}$. However, all rates resulted in yield increases over the control without $\mathrm{P}$, after six years of evaluation (Table 2). Similar to the 2008 growing season presented in this study, linear productivity increases were observed in the growing seasons from 2003 to 2005 and in that of 2007 due to $\mathrm{P}_{2} \mathrm{O}_{5}$ applications, however, lower slopes were observed in the response curves (Guerra et al., 2008).

The coffee leaf $\mathrm{P}$ content reached a maximum $\left(1.98 \mathrm{~g} \mathrm{~kg}^{-1}\right)$ by an application of $270 \mathrm{~kg} \mathrm{ha}^{-1} \mathrm{P}_{2} \mathrm{O}_{5}$ (Figure 1b). This result showed that coffee accumulates more $\mathrm{P}$ at higher soil availability, but certainly there is some restriction to nutrient accumulation, because the leaf contents tended to stabilize from the rate of $270 \mathrm{~kg} \mathrm{ha}^{-1} \mathrm{P}_{2} \mathrm{O}_{5}$. It is important to mention that the coffee leaf $\mathrm{P}$ contents are highest at the time leaves were sampled (Laviola et al., 2007).

Without considering specific coffee-producing regions, Martinez et al. (2003) showed a leaf P sufficiency range from 1.2 to $2.0 \mathrm{~g} \mathrm{~kg}^{-1}$, by which all leaf $\mathrm{P}$ contents of this study would be considered appropriate. It should be mentioned that no appropriate, specifically studied $\mathrm{P}$ ranges have been determined for coffee in the area of Planaltina, DF; it would not be correct to assume that all treatments had appropriate soil P levels, since the treatments differed significantly in coffee yield (Figure 1a). In this context, it is noteworthy that the highest average coffee yield (129.7 bags ha ${ }^{-1}$ of processed coffee in 2008), was obtained when the leaf $\mathrm{P}$ content of the plants reached an average value of $1.98 \mathrm{~g} \mathrm{~kg}^{-1}$.

The forms of $\mathrm{P}$ considered available for coffee were those determined by the routine extractors, Mehlich-1

Table 2. Coffee yield averages of irrigated coffee, after six years of production, as a function of $\mathrm{P}_{2} \mathrm{O}_{5}$ rates in a LVd

\begin{tabular}{|c|c|c|c|c|}
\hline $\mathrm{P}_{2} \mathrm{O}_{5}$ Dose & $2003 / 04 / 05$ & 2007 & 2008 & General Average \\
\hline $\mathrm{kg} \mathrm{ha}^{-1}$ & & 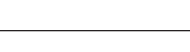 & $a^{-1}$ & 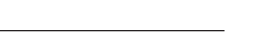 \\
\hline 0 & $41.6(100 \%)^{(1)}$ & $49.9(100 \%)$ & $50.7(100 \%)$ & $37.6(100 \%)$ \\
\hline 50 & $45.4(109 \%)$ & $51.0(102 \%)$ & $63.7(126 \%)$ & $41.8(111 \%)$ \\
\hline 100 & $49.2(118 \%)$ & $52.3(105 \%)$ & $73.3(145 \%)$ & $45.5(121 \%)$ \\
\hline 200 & $56.9(137 \%)$ & $64.0(128 \%)$ & 100. $3(198 \%)$ & $55.8(148 \%)$ \\
\hline 400 & $72.1(173 \%)$ & $77.4(155 \%)$ & $125.7(248 \%)$ & $69.9(186 \%)$ \\
\hline
\end{tabular}

(1) Numbers in brackets refer to the yield percentage compared to the control (rate $0=100 \%)$ * As the trees were pruned in 2005 , there was no production in 2006. However, this year was also considered in the overall average; ** Data for this experiment cited from Guerra et al. (2008). 

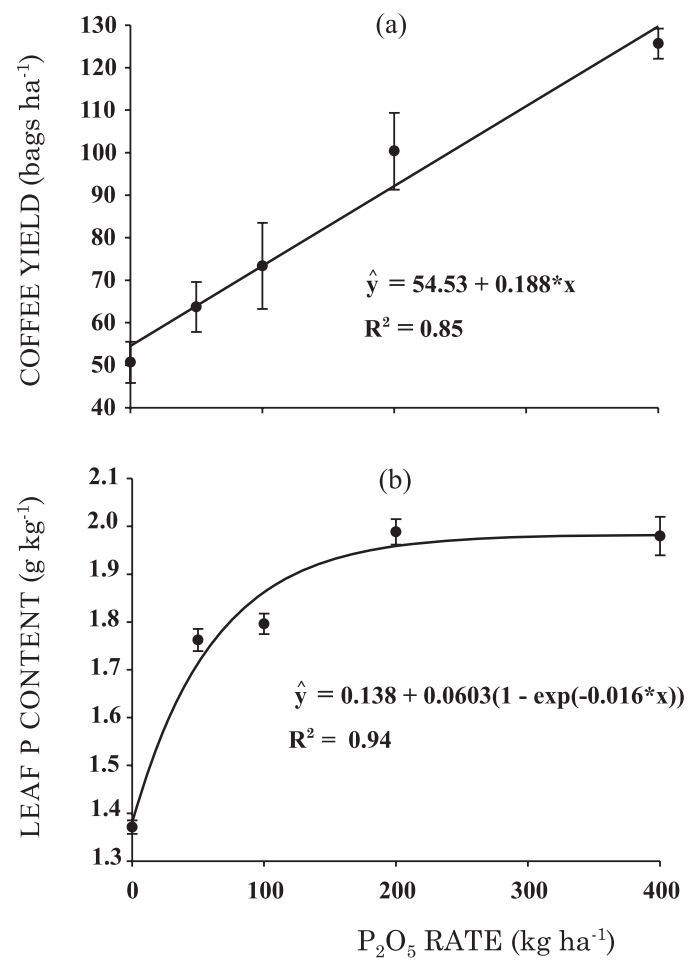

Figure 1. Coffee yield (a) and leaf phosphorus contents (b) of irrigated coffee fertilized with different annual phosphorus rates in a Red Latosol (Oxisol) (harvest 2008). * Significant by t test at $5 \%$.

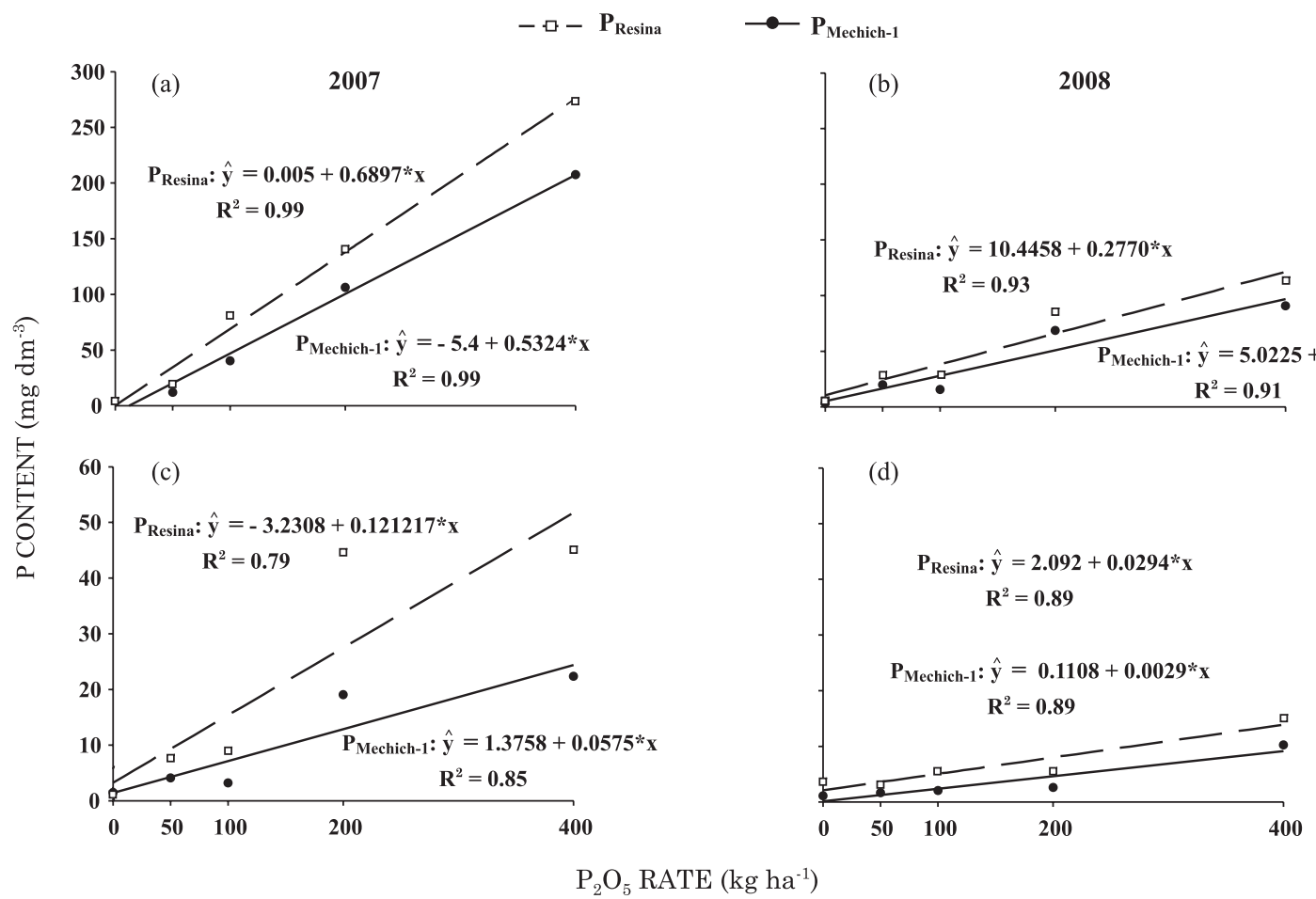

Figure 2. Contents of available phosphorus in the soil by Mehlich-1 and ion exchange resin extractors, in function of annual application of phosphorus rates, in samples collected in two years ( $a$ and $b=d e p t h$ of 0-10 cm; C and D depth of 10-20 cm). * Significant by t test at $5 \%$. and ionic exchange resin, and the labile fractions obtained by the fractionation of Hedley et al. (1982), consisting of the sum of $\mathrm{Pi}+\mathrm{Po}-\mathrm{NaHCO}_{3} 0.5 \mathrm{~mol} \mathrm{~L}^{-1}$. This subdivision has the purpose of understanding $\mathrm{P}$ dynamics and availability in the soil better (Rheinheimer et al., 2008).

With regard to available $\mathrm{P}$, a similar behavior was observed in the results obtained by routine extractors (Figure 2) and by fractionation (Figure 3), which reveal increases in the $\mathrm{P}$ contents as a function of increasing $\mathrm{P}_{2} \mathrm{O}_{5}$ rates applied during the two years. Although the contents of labile $\mathrm{P}$ obtained by Hedley et al. (1982) increased by annual $\mathrm{P}_{2} \mathrm{O}_{5}$ application (Figure 3), when their contents were analyzed for total recovered soil $\mathrm{P}$ as described by Bowman (1989), it was observed that they remained constant and low, even after phosphate fertilizations during two years of study (Table 3), demonstrating little participation of this compartment in soil total $\mathrm{P}$.

The highest available $\mathrm{P}$ contents were obtained at the depth of 0-10 cm, in the two studied years, which is coherent with the low soil mobility of the nutrient, because the fertilizers for coffee are applied to the soil surface, without incorporation. The available $\mathrm{P}$ contents, in a general way, tended to decrease from 2007 to 2008 , certainly because of the plant demands for vegetative and reproductive growth and a remarkable coffee yield in 2008 (Figure 1). Linear adjustments were obtained for this layer, for all available $\mathrm{P}$ forms (Figure 2 ). 


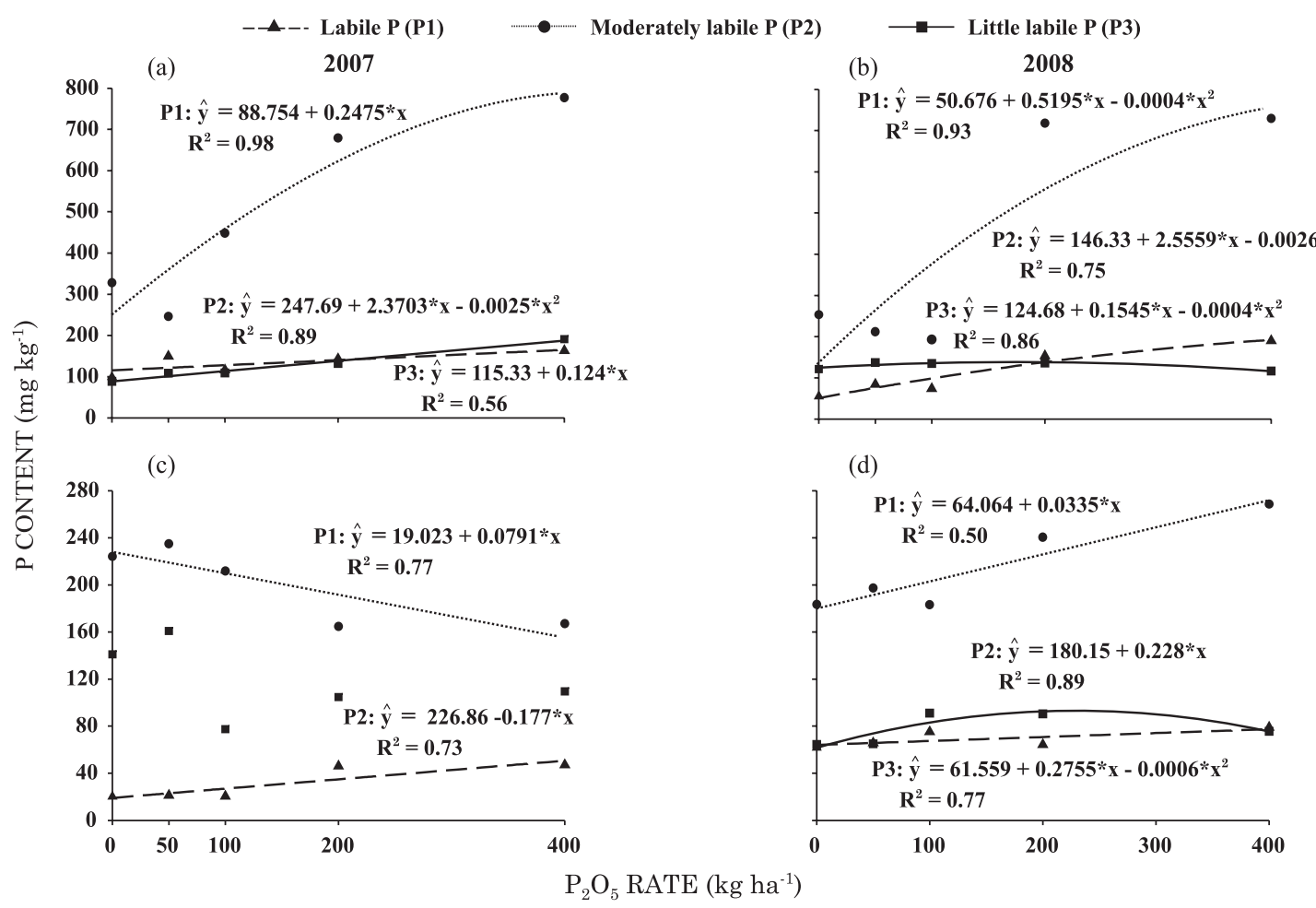

Figure 3. Contents of labile, moderately labile and low labile soil phosphorus in samples collected in two years (a and $b=$ depth of $0-10 \mathrm{~cm}$; $c$ and d depth of 10-20 cm) by the extractors $\mathrm{NaHCO}_{3} 0.5 \mathrm{~mol} \mathrm{~L}^{-1}$, $\mathrm{NaOH} 0.1 \mathrm{~mol} \mathrm{~L}^{-1}$ and $\mathrm{NaOH} 0.5 \mathrm{~mol} \mathrm{~L}^{-1}$, respectively, in function of annual phosphorus application. * Significant by t test at $5 \%$.

The levels of $\mathrm{P}$ availability considered very good for the soil at the depth of $0-20 \mathrm{~cm}$ are 9.0 and $30 \mathrm{mg} \mathrm{dm}{ }^{-3}$ by Mehlich-1 (CFSEMG, 1999) and by ionic exchange resin (Raij et al., 1997), respectively. According to these recommendations, for an expected production of 70 bags ha-1 $^{-1}$, given the above mentioned contents, 0 or $30 \mathrm{~kg} \mathrm{ha}^{-1} \mathrm{P}_{2} \mathrm{O}_{5}$ should be applied. When these recommended rates are substituted in the estimated equation of coffee yield in function of annual $\mathrm{P}_{2} \mathrm{O}_{5}$ rates (Figure 1a), approximately 54.5 and 60.2 bags ha $^{-1}$ are obtained, less than 70 bags expected and very far from the 129.7 bags obtained by $400 \mathrm{~kg} \mathrm{ha}{ }^{-1} \mathrm{P}_{2} \mathrm{O}_{5}$ application. Therefore, the currently recommended fertilization rates are not appropriate for irrigated coffee.

The adjustment of the $\mathrm{P}$ forms in the $10-20 \mathrm{~cm}$ layer was also linear (Figure 2). Because the phosphate fertilization was applied to the surface without incorporation, the $\mathrm{P}$ contents in this layer are usually much lower than in $0-10 \mathrm{~cm}$. In general, it was noticed that $\mathrm{P}$ contents in $10-20 \mathrm{~cm}$, by routine extractors, decreased more abruptly from 2007 to 2008 , compared to those of the top layer $(0-10 \mathrm{~cm})$. This evidences nutrient extraction from that layer and its concomitant non-replacement as quickly as it occurs in the 0-10 cm layer. On the other hand, the behavior of labile $\mathrm{P}$ by the fractionation extractor of Hedley et al. (1982) did not follow this tendency in the 10-20 cm layer and increased from 2007 to 2008 , although the magnitude of the contents in this layer was lower in the two years of study.

The available $\mathrm{P}$ is quickly associated to the phosphate compound group capable of quickly restoring $\mathrm{P}$ in the soil solution when it is absorbed by plants. It is known that the most labile fractions are dependent on the degree of soil weathering-leaching, texture, mineralogy, organic matter level, physiochemical characteristics, biological activity, and predominant vegetation (Rheinheimer et al., 2008). The available $P$ fraction behavior can be explained by the fact that the annual phosphate fertilizations increase the saturation percentage of $\mathrm{P}$ bonding sites on the soil colloid surface, allowing a negative charge increase and consequently, lower adsorption of $\mathrm{P}$ applied. Phosphorus adsorption, through internal sphere complexes in $\mathrm{Fe}$ and $\mathrm{Al}$ oxides, causes the negative charge increase on the soil particle surface, increasing the negative electric surface potential (Lima et al., 2000), as well as the net electric charge and effective CEC (Dynia \& Camargo, 1998), even in highly weathered soils, such as Latosols of the Brazilian Central Plateau (Cerrado area).

The highest contents of extracted $\mathrm{P}$ in the fractionation of Hedley et al. (1982) were obtained with $\mathrm{NaOH} 0.1 \mathrm{~mol} \mathrm{~L}^{-1}$, classified as a moderately labile $\mathrm{P}$ 
Table 3. Phosphorus fractions in a dystrophic Red Latosol (Oxisol) under coffee fertilized with different $P$ levels, in 2007 and 2008

\begin{tabular}{|c|c|c|c|c|c|}
\hline \multirow{2}{*}{ Soil phosphorus fraction } & \multicolumn{5}{|c|}{$\mathrm{P}_{2} \mathrm{O}_{5}$ rate $\left(\mathrm{kg} \mathrm{ha}^{-1}\right)$} \\
\hline & $\mathbf{0}$ & 50 & 100 & 200 & 400 \\
\hline & & & $-\mathrm{mg} \mathrm{kg}^{-1}$ & & \\
\hline & & & 2007 & & \\
\hline & & & Depth $0-10 \mathrm{~cm}$ & & \\
\hline Labile & $88(21 \%)^{(1)}$ & $109(16 \%)$ & $109(11 \%)$ & $132(10 \%)$ & $191(15 \%)$ \\
\hline Moderately labile P & $327(76 \%)$ & $246(37 \%)$ & $448(46 \%)$ & $679(50 \%)$ & $776(60 \%)$ \\
\hline Little labile $\mathrm{P}$ & $99(23 \%)$ & $149(23 \%)$ & $116(12 \%)$ & $143(11 \%)$ & $163(13 \%)$ \\
\hline P- $\Sigma$ (Hedley) & $514(120 \%)$ & $504(76 \%)$ & $673(69 \%)$ & $953(70 \%)$ & $1130(88 \%)$ \\
\hline Total P & $429(100 \%)$ & $664(100 \%)$ & $977(100 \%)$ & $1359(100 \%)$ & $1286(100 \%)$ \\
\hline \multirow[t]{2}{*}{ Residual P- in Bowman } & - & $160(24 \%)$ & $304(31 \%)$ & $406(30,0 \%)$ & $156(12 \%)$ \\
\hline & & & Depth $10-20 \mathrm{~cm}$ & & \\
\hline Labile & $20(7 \%)$ & $21(7 \%)$ & $20(5 \%)$ & $46(7 \%)$ & $47(6 \%)$ \\
\hline Moderately labile P & $224(77 \%)$ & $235(74 \%)$ & $21(54 \%)$ & $164(24 \%)$ & $167(21 \%)$ \\
\hline Little labile $\mathrm{P}$ & $141(49 \%)$ & $161(51 \%)$ & $77(20 \%)$ & $105(15 \%)$ & $110(14 \%)$ \\
\hline P- $\Sigma$ (Hedley) & $385(133 \%)$ & $417(132 \%)$ & $309(79 \%)$ & $315(45 \%)$ & $324(40 \%)$ \\
\hline Total P & $290(100 \%)$ & $316(100 \%)$ & $393(100 \%)$ & $698(100 \%)$ & $801(100 \%)$ \\
\hline \multirow[t]{2}{*}{ Residual P- in Bowman } & - & - & $84(21 \%)$ & $383(55 \%)$ & $477(60 \%)$ \\
\hline & & & $\begin{array}{c}2008 \\
\text { Depth 0-10 cm }\end{array}$ & & \\
\hline Labile & $55(9 \%)$ & $84(9 \%)$ & $74(9 \%)$ & $153(11 \%)$ & $190(13 \%)$ \\
\hline Moderately labile P & $253(43 \%)$ & $211(23 \%)$ & $192(22 \%)$ & $718(52 \%)$ & $729(50 \%)$ \\
\hline Little labile $\mathrm{P}$ & $121(21 \%)$ & $137(15 \%)$ & $135(15 \%)$ & $136(10 \%)$ & $117(8 \%)$ \\
\hline P- $\Sigma$ (Hedley) & $428(73 \%)$ & $432(47 \%)$ & $400(46 \%)$ & $1007(73 \%)$ & $1035(71 \%)$ \\
\hline Total P & $584(100 \%)$ & $922(100 \%)$ & $873(100 \%)$ & $1371(100 \%)$ & $1455(100 \%)$ \\
\hline \multirow[t]{2}{*}{ Residual P- in Bowman } & $155(27 \%)$ & $490(53 \%)$ & $473(54 \%)$ & $365(27 \%)$ & $420(29 \%)$ \\
\hline & & & Depth $10-20 \mathrm{~cm}$ & & \\
\hline Labile & $62(17 \%)$ & $66(17 \%)$ & $75(17 \%)$ & $64(11 \%)$ & $79(13 \%)$ \\
\hline Moderately labile P & $183(50 \%)$ & $197(50 \%)$ & $183(40 \%)$ & $240(40 \%)$ & $269(43 \%)$ \\
\hline Little labile $\mathrm{P}$ & $64(18 \%)$ & $65(16 \%)$ & $91(20 \%)$ & $91(15 \%)$ & $76(12 \%)$ \\
\hline P- $\Sigma$ (Hedley) & 309 (85\%) & $328(82 \%)$ & $349(77 \%)$ & $395(65 \%)$ & $423(67 \%)$ \\
\hline Total P & $363(100 \%)$ & $398(100 \%)$ & $455(100 \%)$ & $606(100 \%)$ & $628(100 \%)$ \\
\hline Residual P- in Bowman & $54(15 \%)$ & $70(18 \%)$ & $106(23 \%)$ & $212(35 \%)$ & $205(33 \%)$ \\
\hline
\end{tabular}

(1) Percentage values relative to Total P Bowman. Samples in which Residual P could not be estimated. Labile P: Pi $+\mathrm{Po}_{\mathrm{NaHCO}}$ $0.5 \mathrm{~mol} \mathrm{~L}^{-1}$; Moderately labile P: $\mathrm{Pi}+\mathrm{Po} \mathrm{NaOH} 0.1 \mathrm{M}$; Little labile P = Pi + Po NaOH $0.5 \mathrm{~mol} \mathrm{~L}^{-1}$; $\Sigma$ - Hedley: Labile P + Moderately labile P + Little labile P; Total P Bowman: P determined according to (Bowman, 1989); Residual P in Bowman: Total P Bowman - P- $\sum$ (Hedley).

fraction (Table 3). Except for the depth of 10-20 cm, in 2007, the $\mathrm{P}$ contents increased in the two depths in function of the increase of applied $\mathrm{P}_{2} \mathrm{O}_{5}$ rates (Figure 3); a quadratic adjustment for the two years was observed in the $0-10 \mathrm{~cm}$ layer (Figure $3 \mathrm{a}, \mathrm{b})$. In 2008, the behavior in the 0-20 cm layer was similar to that of the others; the moderately labile $\mathrm{P}$ contents increased in function of soil application of $\mathrm{P}_{2} \mathrm{O}_{5}$. In general, at the depth of $0-10 \mathrm{~cm}$, the contents decreased from one year to the other, probably in function of nutrient absorption by coffee plants (Figure 1).

The results agree with those in the literature, once in more oxidic and weathered-leached soils, such as Latosols under Cerrado, the compartment represented by moderately labile $\mathrm{P}$ is considered the strongest soil $\mathrm{P}$ drain (Conte et al., 2003) and is closely related to $\mathrm{Fe}$ and $\mathrm{Al}$ oxides and stable humic compounds (Hedley et al., 1982). However, the moderately labile $\mathrm{P}$ fraction is probably still in equilibrium with soil solution $\mathrm{P}$, and can therefore supply the plants with $\mathrm{P}$ in the subsequent production cycles (Novais et al., 2007).

The results for the low labile $\mathrm{P}$ compartment were only significant for the 0-10 cm layer in both years and for the 0-20 cm layer in 2008 (Figure 3). In the 0-10 cm layer, in 2007, the low labile P contents had a linear behavior in function of $\mathrm{P}_{2} \mathrm{O}_{5}$ rates (Figure $3 \mathrm{a}$ ). However, when these contents were analyzed in the 0-10 (Figure 3b) and 10-20 cm layers (Figure 3d) in 2008, the quadratic adjustment indicated increases up to maximum values of 193.1 and $229.6 \mathrm{~kg} \mathrm{ha}^{-1} \mathrm{P}_{2} \mathrm{O}_{5}$ in the layers $0-10$ and $10-20 \mathrm{~cm}$, respectively, and from then on, the values decline. It should be mentioned that the $\mathrm{P}$ contents in this compartment were intermediate, compared to labile $\mathrm{P}$ and moderately labile $\mathrm{P}$ fractions. This is important, since the plant availability of the low labile $\mathrm{P}$ fraction (Table 3 ) is considered low (Rheinheimer et al., 2000). 
When the behavior of low labile $\mathrm{P}$ is observed in 2008, the amount of P decreased as the amount of phosphate applied increased. This shows that low labile $\mathrm{P}$ fraction adsorption sites were saturated until the rates corresponding to the peak values or maybe that low labile $\mathrm{P}$ only became available to coffee when the contents corresponded to these rates of peak values, as related to the coffee yield. These results are extremely important, because, as a rule, when $\mathrm{P}$ is applied to the soil, the adsorption initially occurs at the sites with higher chemical stability and, later, the nutrient is redistributed in fractions retained with lower energy and higher plant availability (Rheinheimer et al., 2000; Conte et al., 2003).

When analyzing the relative values of participation of each fraction compared to the total $\mathrm{P}$ fraction extracted as proposed by Bowman, it was observed that in general, low labile $\mathrm{P}$ decreased with the increase of $\mathrm{P}_{2} \mathrm{O}_{5}$ rates, in 2007 as well as 2008 (Tables 3 and 4). On the other hand, it can also be verified that residual $\mathrm{P}$, estimated by the difference between total $\mathrm{P}$ fraction according to Bowman and bioavailable $\mathrm{P}$, tended to increase with increasing rates. In this context, low labile $\mathrm{P}$ may be transformed into a chemically stable, even more recalcitrant form. This occurs due to the contact time of the nutrient with the soil clay minerals and oxides, because specific reactions occur which confer higher chemical stability to the bond between $\mathrm{P}$ and soil. Therefore, the nutrient tends to move towards the non-labile fractions that are no longer in equilibrium with soil solution (Novais et al., 2007), in other words, it is practically impossible for the plant to absorb $\mathrm{P}$ from the residual $\mathrm{P}$ compartment. In this case, in spite of the pronounced coffee yield, the nutrient seems to be more available for the plants up to the maximum rates (Figure 3b,d), close to $200 \mathrm{~kg} \mathrm{ha}^{-1} \mathrm{P}_{2} \mathrm{O}_{5}$. Thereafter, $\mathrm{P}$ availability tends to be lower, according to the fractionation model applied. This finding was confirmed by the increased leaf $\mathrm{P}$ contents that tend to stabilize near this $\mathrm{P}_{2} \mathrm{O}_{5}$ rate.

The sum of the labile, moderately labile and little labile fractions, obtained by Hedley et al. (1982), or P$\sum$ (Hedley), still in equilibrium with the soil solution, was considered as bioavailable $\mathrm{P}$ in this study (Novais et al., 2007). The general tendency of the total recovered $\mathrm{P}$ (Bowman, 1989) and bioavailable $\mathrm{P}$ in the soil was of increasing $\mathrm{P}$ contents in function of the $\mathrm{P}_{2} \mathrm{O}_{5}$ rates applied (Figure 4). Bioavailable $\mathrm{P}$ in the layer $10-20 \mathrm{~cm}$ in 2007 was the only exception (Figure 4b), but in 2008, the $\mathrm{P}$ contents in this layer began to behave similarly to those of the surface-nearer layers (Figure 4d).

The bioavailable $\mathrm{P}$ evaluation is important to show the general $\mathrm{P}$ behavior in the soil, because these $\mathrm{P}$ forms affect the bioavailability of this nutrient (Gatiboni et al., 2007). As a result, when observing

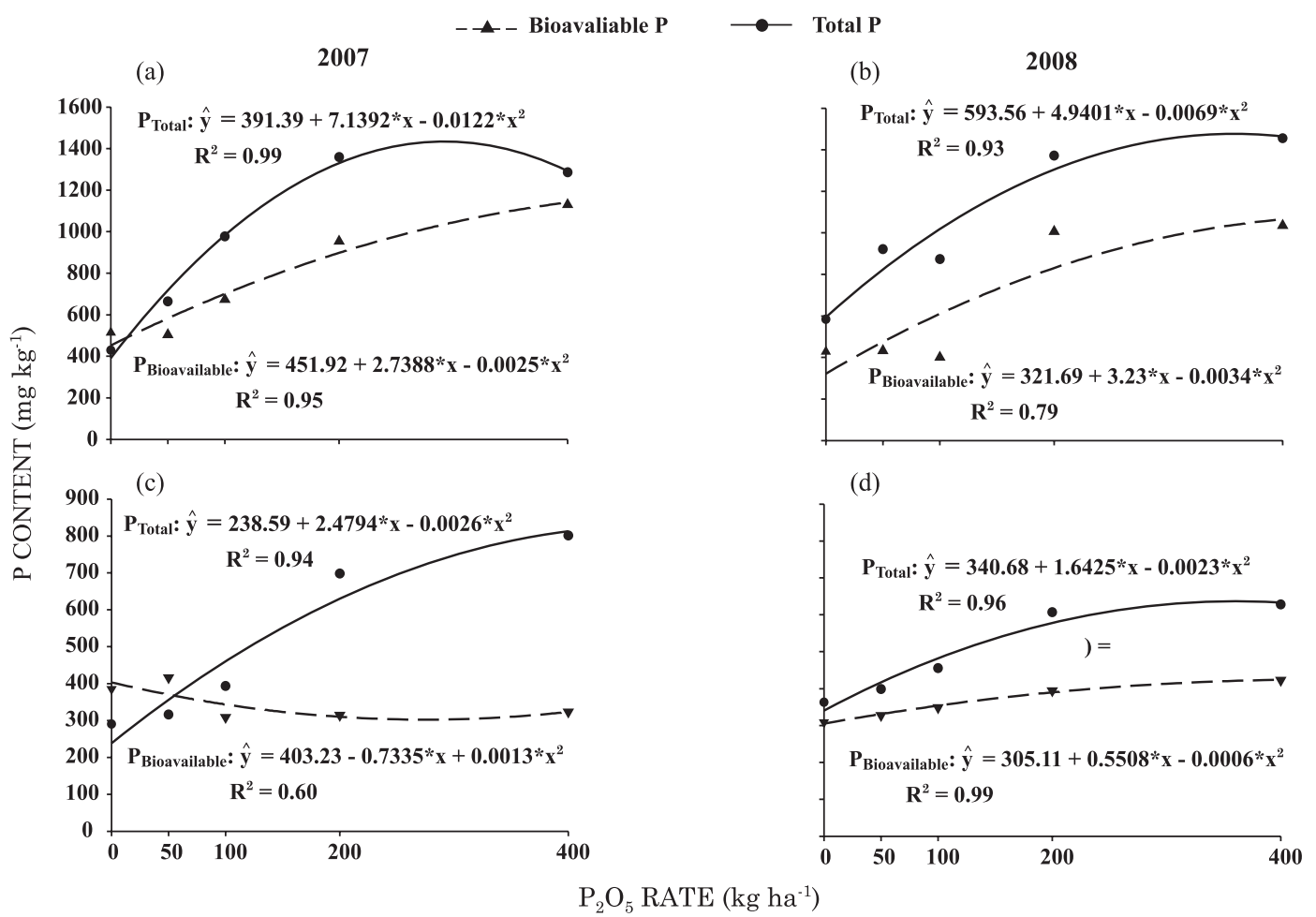

Figure 4. Contents of bioavailable phosphorus fractions (Hedley) and total recovered phosphorus in soil samples collected in two years ( $a$ and $b=$ depth of $0-10 \mathrm{~cm}, c$ and $c=$ depth of 10-20 cm), in function of annual phosphorus applications. * Significant by t test at $5 \%$. 
the relative participation of $\mathrm{P}$ forms in relation to total $\mathrm{P}$ according to Bowman, there is evidence that moderately labile $\mathrm{P}$ forms, available in the medium term, are predominant in the soil (Table 3).

The P- $\sum$ (Hedley) or bioavailable $\mathrm{P}$ contents decreased from the first to the second year (Table 3). Part of this was attributed to the absorption by coffee plants due to the differences in yield. On the other hand, when total P Bowman contents are analyzed, in a more drastic extraction, it was verified that the values were mostly higher than bioavailable $\mathrm{P}$ and they keep on increasing from the first to the second year with the $\mathrm{P}$ rate applications, even after a great coffee yield. This demonstrates that a great part of soil $\mathrm{P}$ applied is accumulated in non-bioavailable form, which was already expected due to the high soil $\mathrm{P}$ retention capacity. In this context, it is known that P from these "non-available" compartments or residual $\mathrm{P}$ is related to $\mathrm{Fe}$ and $\mathrm{Al}$ oxides and to highly stable organic matter (Rheinheimer et al., 2008), and the nutrient in these compounds will hardily become available to plants again (Novais et al., 2007).

Evaluating the non-labile $\mathrm{P}$ reversibility in Latosols, Fernández R. et al. (2008) were able to recover between 26 and $46 \%$ of applied $\mathrm{P}$ in more oxidic soils, after 10 successive extractions with ionic exchange resin. According to these authors, the nonlabile $\mathrm{P}$ forms are dependent on goethite and gibbsite, the latter being the clay mineral with most restrictions to P desorption. Pozza et al. (2009) verified that more than $50 \%$ of the adsorbed phosphate was retained in gibbsite and was not released to the equilibrium solution.

\section{CONCLUSIONS}

1. The irrigated coffee responded to phosphate fertilization in the production phase, with gains of up to $138 \%$ in coffee yield by the application of $400 \mathrm{~kg} \mathrm{ha}^{-1}$ $\mathrm{P}_{2} \mathrm{O}_{5}$, in the studied growing season.

2. The coffee leaf $\mathrm{P}$ contents increased with $\mathrm{P}$ applications, beginning with a rate of $270 \mathrm{~kg} \mathrm{ha}^{-1} \mathrm{P}_{2} \mathrm{O}_{5}$, and stabilized around $1.98 \mathrm{~g} \mathrm{~kg}^{-1}$.

3. Soil $\mathrm{P}$ application caused, in general, an increase in bioavailable $\mathrm{P}$ fractions, which is the main soil $\mathrm{P}$ reservoir.

\section{ACKNOWLEDGEMENTS}

The authors thank the Brazilian Consortium for Research and Coffee Development - CBP\&D-Café and National Institute of Coffee Science and Technology - INCT-Café for supporting this research, the National Council of Scientific and Technological Development - CNPq, for granting scholarships and the Minas Gerais Research Support Foundation - FAPEMIG, for financial support to carry out this research project.

\section{LITERATURE CITED}

BHADORIA, P.S.; STEINGROBE, B.; CLAASSEN, N. \& LIEBERSBACH, H. Phosphorus efficiency of wheat and sugar beet seedlings grown in soils with mainly calcium, or iron and aluminum phosphate. Plant Soil, 246:41-52, 2002.

BOWMAN, R.A. A sequential extraction procedure whit concentrated sulfuric acid and dilute base for soil organic phosphorus. Soil Sci. Soc. Am. J., 53:362-366, 1989.

COMISSÃO DE FERTILIDADE DE SOLO DO ESTADO DE MINAS GERAIS - CFSEMG. Recomendações para o uso de corretivos e fertilizantes em Minas Gerais: $5^{\text {a }}$ aproximação. Viçosa, MG, 1999. p.289-302.

CONTE, E.; ANGHINONI, I. \& RHEINHEIMER, D.S. Frações de fósforo acumuladas em Latossolo argiloso pela aplicação de fosfato no sistema plantio direto. R. Bras. Ci. Solo, 27:893-900, 2003

DYNIA, J.F. \& CAMARGO, O.A. Effects of liming, green manuring, and phosphate addition on electrochemical attributes of an Oxisol from central Brazil. Comm. Soil Sci. Plant Anal., 29:755-762, 1998.

EMPRESA BRASILEIRA DE PESQUISA AGROPECUÁRIA EMBRAPA. Manual de análises químicas de solos, plantas e fertilizantes. 2.ed. Brasília, Embrapa Informação Tecnológica, 2009. 627p.

FERNÁNDEZ R., I.E.; NOVAIS, R.F.; NUNES, F.N. \& KER, J.C. Reversibilidade de fósforo não-lábil em solos submetidos à redução microbiana e química. II - Extrações sucessivas do fósforo pela resina de troca aniônica. R. Bras. Ci. Solo, 32:2319-2330, 2008.

FERREIRA, D.F. Análises estatísticas por meio do SISVAR para Windows versão 4.0. In: REUNIÃO ANUAL DA REGIÃO BRASILEIRA DA SOCIEDADE INTERNACIONAL DE BIOMETRIA, 45., 2000, São Carlos. Anais... São Carlos, Universidade Federal de São Carlos, 2000. p.255-258.

GALLO, P.B.; RAIJ, B.van; QUAGGIO, J.A. \& PEREIRA, L.C.E. Resposta de cafezais adensados à adubação NPK. Bragantia, 58:341-351, 1999.

GATIBONI, L.C.; KAMINSKI, J.; RHEINHEIMER, D.S. \& FLORES, J.P.C. Biodisponibilidade de formas de fósforo acumuladas em solo sob sistema plantio direto. R. Bras. Ci. Solo, 31:691-699, 2007.

GUERRA, A.F.; ROCHA, O.C.; RODRIGUES, G.C.; SANZONOWICZ, C.; RIBEIRO FILHO, G.C.; TOLEDO, P.M.R. \& RIBEIRO, L.F. Sistema de produção de café irrigado: Um novo enfoque. ITEM, 73:52-61, 2007. 
GUERRA, A.F.; RODRIGUES, G.C.; ROCHA, O.C.; SANZONOWICZ, C. \& RIBEIRO FILHO, G.C. Resposta do cafeeiro arabica a aplicação de fósforo. In: SIMPÓSIO BRASILEIRO DE PESQUISA EM CAFEICULTURA IRRIGADA, 10., 2008, Araguari. Anais... Araguari, Embrapa Café, 2008. p.62-66.

HEDLEY, M.J.; STEWARD, W.B. \& CHAUHAN, B.S. Changes in inorganic and organic soil phosphorus fraction induced by cultivation practices and laboratory incubation. Soil Sci. Soc. Am. J., 46:970-976, 1982.

LAVIOLA, B.G.; MARTINEZ, E.M.P.; SOUZA, R.B. \& ALVAREZ V., V.H. Dinâmica de P e S em folhas, flores e frutos de cafeeiro arábico em três níveis de adubação. Biosci. J., 23:29-40, 2007.

LIMA, J.M.; ANDERSON, S.J. \& CURI, N. Phosphate-induced clay dispersion as related to aggregate size and composition in hapludoxs. Soil Sci. Soc. Am. J., 64:895-897, 2000.

MARTINEZ, H.E.P.; MENEZES, J.F.S.; SOUZA, R.B.; ALVAREZ V., V.H. \& GUIMARÃES, P.T.G. Faixas críticas de concentrações de nutrientes e avaliação do estado nutricional de cafeeiros em quatro regiões de Minas Gerais. Pesq. Agropec. Bras., 38:703-713, 2003.

MEHRA, O.P. \& JACKSON, M.L. Iron oxide removal from soils and clays by a dithionite-citrate system buffered with sodium bicarbonate. Clays Clay Miner., 7:317-327, 1960.

MURPHY, J. \& RILEY, J.P. A modified single solution method for the determination of phosphate in natural waters. Anal. Chim. Acta, 27:31-36, 1962.

NOVAIS, R.F.; SMYTH, T.J. \& NUNES, F.N. Fósforo. In: NOVAIS, R.F.; ALVAREZ V., V.H.; BARROS, N.F.; FONTES, R.L.F.; CANTARUTTI, R.B. \& NEVES, J.C.L., eds. Fertilidade do solo. Viçosa, MG, Sociedade Brasileira de Ciência do Solo, 2007. p.471-550.

POZZA, A.A.A.; CURI, N.; GUILHERME, L.R.G.; MARQUES, J.J.; COSTA, E.T.S.; ZULIANI, D.Q.; MOTTA, P.E.F.; MARTINS, R.S. \& OLIVEIRA, L.C.A. Adsorção e dessorção aniônicas individuais por gibbsita pedogenética. Química Nova, 32:99-105, 2009.

PREZOTTI, L.C. \& ROCHA, A.C. Nutrição do cafeeiro arábica em função da densidade de plantas e da fertilização com NPK. Bragantia, 63:239-251, 2004.

RAIJ, B.van. Fósforo no solo e interação com outros elementos. In: YAMADA, T. \& ABDALLA, S.R.S., eds. Fósforo na agricultura brasileira. Piracicaba, Potafos/Anda, 2004. p.107-116.
RAIJ, B.van.; ANDRADE, J.C.; CANTARELLA.H. \& QUAGGIO, J.A. Análise química para avaliação da fertilidade de solos tropicais. Campinas, Instituto Agronômico de Campinas, 2001. 285p.

RAIJ, B.van; CANTARELLA, H.; QUAGGIO, J.A. \& FURLANI, A.M.C., eds. Recomendações de adubação e calagem para o Estado de São Paulo. 2.ed. Campinas, Instituto Agronômico/Fundação IAC, 1997. 285p.

RAIJ, B.van. \& QUAGGIO, J.A. Determinação de fósforo, cálcio, magnésio e potássio extraídos com resina trocadora de íons. In: RAIJ, B.van.; ANDRADE, J.C.; CANTARELLA, H. \& QUAGGIO, J.A., eds. Análise química para avaliação da fertilidade de solos tropicais. Campinas, Instituto Agronômico de Campinas, 2001. p.189-199.

RESENDE, M.; BAHIA FILHO, A.F.C. \& BRAGA, J.M. Mineralogia da argila de Latossolos estimada por alocação a partir do teor total de óxidos do ataque sulfúrico. R. Bras. Ci. Solo, 11:17-23, 1987.

RHEINHEIMER, D.S.; ANGHINONI, I. \& KAMINSKI, J. Depleção do fósforo inorgânico de diferentes frações provocada pela extração sucessiva com resina em diferentes solos e manejos. R. Bras. Ci. Solo, 24:345-354, 2000 .

RHEINHEIMER, D.S.; GATIBONI, L.C. \& KAMINSKI, J. Fatores que afetam a disponibilidade do fósforo e o manejo da adubação fosfatada em solos sob sistema de plantio direto. Ci. Rural, 38:576-586, 2008.

SCHWERTMANN, U. Differenzienrung der Eisenoxide des Bödens durch Extraktion mit Ammoniumoxalat-lösung. Z. Pflanzenernahr Bodenkd., 105:105-202, 1964.

SILVA, M.A.; NOBREGA, J.C.A.; CURI, N.; SIQUEIRA, J.O.; MARQUES, J.J.G.S.M. \& MOTTA, P.E.F. Frações de fósforo em Latossolos. Pesq. Agropec. Bras., 38:1197-1207, 2003.

SOUSA, D.M.G.; MIRANDA, L.N. \& OLIVEIRA, S.A. Acidez do solo e sua correção. In: NOVAIS, R.F.; ALVAREZ V., V.H.; BARROS, N.F.; FONTES, R.L.F.; CANTARUTTI, R.B. \& NEVES, J.C.L., eds. Fertilidade do solo. Viçosa, MG, Sociedade Brasileira de Ciência do Solo, 2007. p.205274.

SYERS, J.K.; BROWMAN, M.G.; SAMILLE, G.W. \& COREY, R.B. Phosphate sorption by soils evaluated by the Langmuir adsorption equation. Soil Sci. Soc. Am. Proc., 37:358-363, 1973.

TORRENT, J.; SCHWERTMANN, U.; FETCHER, H. \& ALFEREZ, F. Quantitative relationships between soil color and hematite content. Soil Sci., 136:354-358, 1983. 